\title{
MULTIVARIATE ANALYSIS USED FOR EVALUATION OF THE BIOAVAILABILITY OF HEAVY METALS IN VARIOUS COMPOSTS
}

\author{
OCENA BIOPRZYSWAJALNOŚCI METALI CIĘŻKICH W RÓŻNYCH \\ KOMPOSTACH PRZY UŻYCIU ANALIZY WIELOWYMIAROWEJ
}

\begin{abstract}
Background. Sewage sludge is an urgent environmental problem, which can easily cause secondary pollution. Therefore, it is very important to handle it properly. Composting is a rational method of sewage sludge handling. Composts are valuable sources of nutrients, but at the same time they may pollute the environment with heavy metals. There are various methods of analysis of heavy metals, but there is no method which would provide reliable information about the bioavailabity of heavy metals in various composts.

Materials and methods. The experiment was conducted on 4 different composts made from sewage sludge and bulking agents. The data were analysed by means of multivariate statistical techniques such as MANOVA, Tukey's test for multiple comparisons, principal component analysis and cluster analysis.

Results. The aim of the study was to verify whether multivariate techniques could evaluate the usability of different extractants for assessment of the bioavailability of heavy metals in various composts.

Conclusions. Multivariate statistical techniques help to interpret complex data, where compost, metals and extractants can be analysed in combination. It helps to understand the influence of extractants and metals in the study of sewage sludge.
\end{abstract}

Keywords: bioavailability, composts, heavy metals, extractants, multivariate statistical analysis 
Szabelska-Beręsewicz, A., Jakubus, M., Siatkowski, I. (2018). Multivariate analysis used for evaluation of the bioavailability of heavy metals in various composts. Nauka Przyr. Technol., 12, 2, 221-235. http://dx.doi.org/ 10.17306/J.NPT.00244

\section{Introduction}

Sewage sludge is residue produced in the wastewater treatment process, during which liquids and solids are being separated. Sewage treatment plants in Poland generate about 550,000 Mg of dry matter per year (Central Statistical Office, 2015). Sewage sludge is an urgent environmental problem, which can easily cause secondary pollution. Therefore, it is very important to handle it properly. In Poland the composting of sewage sludge together with bulking agents is a common and generally accepted method of disposal of this noxious waste (Jakubus, 2013). These composts are valuable sources of nutrients and organic matter, which is significant in agricultural and horticultural production. Unfortunately, sewage sludge and sludge-based composts used as soil amendments in modern farming contribute to the input of heavy metals into soil and they affect the behaviour of heavy metals in soil (Rosen and Chen, 2014). There are various single extraction procedures used to measure the content of heavy metals (Kim et al., 2015). Metals are extracted with water, salt solutions, diluted acids and solutions containing chelating or reducing reagents (Jakubus, 2010). However, researchers do not agree about one single extraction procedure which is the best for practical use. It is very hard to indicate the procedure that could be applied for all types of compost and would give reliable results of metal bioavailability.

Therefore, we used multivariate statistical techniques to evaluate the usability of a single extraction procedure for assessment of the bioavailability of heavy metals in various composts.

\section{Materials and methods}

The experiment was conducted on 4 different composts (C1-C4) made from sewage sludge and bulking agents such as straw, sawdust, pine bark, wood chips and hemp waste. Table 1 shows the content of individual components in mixtures. A representative sample was obtained by mixing 4-5 single samples collected from different sampling sites in individual composts. The collected material was dried at $40^{\circ} \mathrm{C}$ and then it was ground and sieved (mesh size $0.25 \mathrm{~mm}$ ). The samples were analysed to measure the content of selected metals $(\mathrm{Cu}, \mathrm{Fe}, \mathrm{Mn}, \mathrm{Ni}, \mathrm{Zn})$. The concentrations of nutrients in the extracts were measured by means of atomic absorption spectrophotometry (ASA) in a Varian Spectra AA 220 FS apparatus. There were three replicates of all assays identifying the content of nutrients in the compost samples.

10 different extractants were used in single extractions (Table 2). The details of the experimental protocols are available elsewhere (Jakubus, 2010; Quevauviller et al., 1998; Zorpas and Loizidou, 2008).

Multivariate statistical techniques (Greenacre and Primicerio, 2013; Mardia et al., 1997; Šmilauer and Lepš, 2014), i.e. multivariate analysis of variance (MANOVA), principal component analysis (PCA) and cluster analysis (CA) were used to analyse the data. Two-way MANOVA was combined with the Hotelling-Lawley test. Next, Tukey's HSD multiple comparison procedure was used separately for the analysis of metals and extractants. The significance level was set at 0.05 . The PCA was combined with the 
Szabelska-Beręsewicz, A., Jakubus, M., Siatkowski, I. (2018). Multivariate analysis used for evaluation of the bioavailability of heavy metals in various composts. Nauka Przyr. Technol., 12, 2, 221-235. http://dx.doi.org/ 10.17306/J.NPT.00244

Table 1. The content of individual components in composts

\begin{tabular}{|l|c|l|c|}
\hline \multicolumn{1}{|c|}{ Component } & \multicolumn{1}{|c|}{$\begin{array}{c}\text { Content } \\
(\%)\end{array}$} & \multicolumn{1}{|c|}{ Component } & $\begin{array}{c}\text { Content } \\
(\%)\end{array}$ \\
\hline \multicolumn{1}{|c|}{ Compost 1 (C1) } & & Sewage sludge & \\
\hline Sewage sludge from Szamotuły & 75 & Sawdust & 39 \\
Sawdust & 20 & Wheat straw & 56 \\
Wheat straw & 5 & \multicolumn{1}{|c|}{ Compost 4 (C4) } & 40 \\
\hline \multicolumn{1}{|c|}{ Compost 2(C2) } & 40 & Sewage sludge from Czarnków & 50 \\
\hline Sewage sludge & 50 & Hemp waste & 10 \\
Pine bark & 10 & Wood cuttings & 5 \\
Sawdust & \multicolumn{2}{|c|}{} \\
\hline
\end{tabular}

Pearson correlation coefficient to create a similarity matrix and subsequently to obtain eigenvalues and eigenvectors. In the CA, the Euclidean distance was used to measure the dissimilarity between the data and the Ward method was used for the cluster.

The R software, version 3.2.1 (R Core Team, 2015) was used for statistical calculations.

Table 2. Single extraction protocols

\begin{tabular}{|c|c|c|}
\hline Extractants & $\begin{array}{c}\text { Compost: } \\
\text { solution } \\
\text { ratio }\end{array}$ & Extraction procedures \\
\hline $\mathrm{HCl}: 1 \mathrm{~mol} \cdot \mathrm{dm}^{-3} \mathrm{HCl}$ & $1: 2$ & $\begin{array}{l}\text { Shaken for } 1 \mathrm{~h} \text { at room temperature. Extract separated } \\
\text { from solid residue by centrifugation for } 10 \text { minutes }\end{array}$ \\
\hline $\mathrm{HCl}: 0.5 \mathrm{~mol} \cdot \mathrm{dm}^{-3} \mathrm{HCl}$ & $1: 2$ & as above \\
\hline $\mathrm{CH}_{3} \mathrm{COOH}: 0.43 \mathrm{~mol} \cdot \mathrm{dm}^{-3} \mathrm{CH}_{3} \mathrm{COOH}$ & $1: 2$ & $\begin{array}{l}\text { Shaken for } 3 \mathrm{~h} \text { at room temperature. Extract separated } \\
\text { from solid residue by centrifugation for } 10 \text { minutes }\end{array}$ \\
\hline $\mathrm{NH}_{4} \mathrm{NO}_{3}: 1 \mathrm{~mol} \cdot \mathrm{dm}^{-3} \mathrm{NH}_{4} \mathrm{NO}_{3}$ & $1: 2$ & $\begin{array}{l}\text { Shaken for } 2 \mathrm{~h} \text { at room temperature. Extract separated } \\
\text { from solid residue by centrifugation for } 10 \text { minutes }\end{array}$ \\
\hline EDTA: $0.05 \mathrm{~mol} \cdot \mathrm{dm}^{-3}$ EDTA, $\mathrm{pH}=7$ & $1: 10$ & $\begin{array}{l}\text { Shaken for } 1.5 \mathrm{~h} \text { at room temperature. Extract separat- } \\
\text { ed from solid residue by centrifugation for } 10 \text { minutes }\end{array}$ \\
\hline Na2EDTA: $0.025 \mathrm{~mol} \cdot \mathrm{dm}^{-3} \mathrm{NA}_{2} \mathrm{EDTA}, \mathrm{pH}=4.62$ & $1: 10$ & as above \\
\hline $\begin{array}{l}\text { FAC: } 0.5 \mathrm{~mol} \cdot \mathrm{dm}^{-3} \mathrm{CH}_{3} \mathrm{COONH}_{4}+\mathrm{CH}_{3} \mathrm{COOH} \\
\text { conc. }+0.02 \mathrm{~mol} \cdot \mathrm{dm}^{-3} \mathrm{EDTA}, \mathrm{pH}=4.65\end{array}$ & $1: 10$ & $\begin{array}{l}\text { Shaken for } 1 \mathrm{~h} \text { at room temperature. Extract separated } \\
\text { from solid residue by centrifugation for } 10 \text { minutes }\end{array}$ \\
\hline $\mathrm{HNO}_{3}: 10 \% \mathrm{HNO}_{3}$ & $1: 20$ & $\begin{array}{l}\text { Shaken for } 3 \mathrm{~h} \text { at room temperature. Extract separated } \\
\text { from solid residue by centrifugation for } 10 \text { minutes }\end{array}$ \\
\hline $\begin{array}{l}\text { DTPA }\left(0.005 \mathrm{~mol} \cdot \mathrm{dm}^{-3} \text { DTPA }+0.1 \mathrm{~mol} \cdot \mathrm{dm}^{-3}\right. \\
\left.\text { TEA }+0.01 \mathrm{~mol} \cdot \mathrm{dm}^{-3} \mathrm{CaCl}_{2}\right), \mathrm{pH}=7.3\end{array}$ & $1: 2$ & as above \\
\hline $\mathrm{CaCl}_{2}: 0.01 \mathrm{~mol} \cdot \mathrm{dm}^{-3} \mathrm{CaCl}_{2}$ & $1: 5$ & as above \\
\hline
\end{tabular}


Szabelska-Beręsewicz, A., Jakubus, M., Siatkowski, I. (2018). Multivariate analysis used for evaluation of the bioavailability of heavy metals in various composts. Nauka Przyr. Technol., 12, 2, 221-235. http://dx.doi.org/ 10.17306/J.NPT.00244

\section{Results and discussion}

\section{MANOVA}

MANOVA was used first due to the design of the experiment. The concentrations of nutrients in four different composts were dependent variables in the model. They were measured for 5 metals obtained by means of 10 extractants. Table 3 shows the results of the MANOVA. All sources, i.e. metals, extractants and interaction of metals with the extractants were statistically significant.

Table 3. Multivariate analysis of variance for two-factor design combined with Hotelling-Lawley test

\begin{tabular}{|l|r|c|c|c|c|c|}
\hline \multicolumn{1}{|c|}{ Source } & Df & Hotelling-Lawley & approx F & num Df & den Df & $\operatorname{Pr}(>\mathrm{F})$ \\
\hline metals & 4 & 1928.28 & 11509.4 & 16 & 382 & $<0.0001^{* * *}$ \\
extractants & 9 & 453.64 & 1203.4 & 36 & 382 & $<0.0001^{* * *}$ \\
metals* extractants & 36 & 1470.59 & 975.3 & 144 & 382 & $<0.0001^{* * *}$ \\
residuals & 100 & & & & & \\
\hline
\end{tabular}

Signif. codes: 0 ‘***’ 0.001 ‘**’ 0.01 '*’ 0.05 ‘’ 0.1 ‘ ’ 1 .

\section{Tukey's HSD test for multiple comparisons}

Since metals and extractants were significant at 0.0001 , the next step involved pairwise comparisons to determine which specific nutrients and extractants were different from each other. The results of Tukey's HSD test are shown in Table 4 and Table 5 for metals and extractants, respectively.

Table 4. Tukey's HSD test for multiple comparisons of metals. Different letters referring to metals in individual composts indicate significant differences between them at 0.05

\begin{tabular}{|l|c|r|l|l|r|l|l|l|l|l|r|r|}
\hline \multicolumn{9}{|c|}{ C1 } & \multicolumn{3}{c|}{ C2 } & \multicolumn{3}{c|}{ C3 } & \multicolumn{3}{c|}{ C4 } \\
\hline metal & group & mean & metal & group & mean & metal & group & mean & metal & group & mean \\
\hline $\mathrm{Fe}$ & $\mathrm{a}$ & 4824 & $\mathrm{Fe}$ & $\mathrm{a}$ & 3580 & $\mathrm{Fe}$ & $\mathrm{a}$ & 2941 & $\mathrm{Fe}$ & $\mathrm{a}$ & 3626 \\
$\mathrm{Zn}$ & $\mathrm{b}$ & 389 & $\mathrm{Zn}$ & $\mathrm{b}$ & 332 & $\mathrm{Zn}$ & $\mathrm{b}$ & 217 & $\mathrm{Zn}$ & $\mathrm{b}$ & 262 \\
$\mathrm{Cu}$ & $\mathrm{c}$ & 128 & $\mathrm{Mn}$ & $\mathrm{c}$ & 125 & $\mathrm{Cu}$ & $\mathrm{c}$ & 81 & $\mathrm{Mn}$ & $\mathrm{c}$ & 124 \\
$\mathrm{Mn}$ & $\mathrm{c}$ & 110 & $\mathrm{Cu}$ & $\mathrm{c}$ & 73 & $\mathrm{Mn}$ & $\mathrm{c}$ & 71 & $\mathrm{Cu}$ & $\mathrm{d}$ & 61 \\
$\mathrm{Ni}$ & $\mathrm{d}$ & 6 & $\mathrm{Ni}$ & $\mathrm{d}$ & 5 & $\mathrm{Ni}$ & $\mathrm{d}$ & 6 & $\mathrm{Ni}$ & $\mathrm{d}$ & 6 \\
\hline
\end{tabular}


Szabelska-Beręsewicz, A., Jakubus, M., Siatkowski, I. (2018). Multivariate analysis used for evaluation of the bioavailability of heavy metals in various composts. Nauka Przyr. Technol., 12, 2, 221-235. http://dx.doi.org/ 10.17306/J.NPT.00244

Table 5. Tukey's HSD test for multiple comparisons of extractants for composts $\mathrm{C} 1$ and $\mathrm{C} 2$. Different letters referring to extractants in individual composts indicate significant differences between them at 0.05

\begin{tabular}{|c|c|c|c|c|c|c|c|c|c|c|c|}
\hline \multicolumn{12}{|c|}{ Composts } \\
\hline \multicolumn{3}{|c|}{$\mathrm{C} 1$} & \multicolumn{3}{|c|}{$\mathrm{C} 2$} & \multicolumn{3}{|c|}{$\mathrm{C} 3$} & \multicolumn{3}{|c|}{$\mathrm{C} 4$} \\
\hline extractant & group & mean & extractant & group & mean & extractant & group & mean & extractant & groups & mean \\
\hline $\mathrm{HCl}$ & $\mathrm{a}$ & 2509 & $\mathrm{HCl1}$ & $\mathrm{a}$ & 1626 & $\mathrm{HCl}$ & $\mathrm{a}$ & 1672 & $\mathrm{HCl1}$ & $\mathrm{a}$ & 2087 \\
\hline $\mathrm{HNO}_{3}$ & $\mathrm{~b}$ & 2226 & $\mathrm{HNO}_{3}$ & $\mathrm{a}$ & 1588 & $\mathrm{HNO}_{3}$ & b & 1228 & $\mathrm{HNO}_{3}$ & $\mathrm{~b}$ & 1843 \\
\hline FAC & b & 2138 & FAC & $\mathrm{b}$ & 1449 & FAC & $\mathrm{c}$ & 961 & FAC & $\mathrm{c}$ & 1162 \\
\hline $\mathrm{HCl05}$ & $\mathrm{c}$ & 1495 & $\mathrm{HCl05}$ & b & 1343 & $\mathrm{HCl05}$ & d & 908 & $\mathrm{HCl05}$ & $\mathrm{c}$ & 1071 \\
\hline EDTA & $\mathrm{c}$ & 1386 & EDTA & $\mathrm{c}$ & 1086 & EDTA & $\mathrm{d}$ & 877 & EDTA & $\mathrm{c}$ & 1012 \\
\hline Na2EDTA & d & 828 & Na2EDTA & $\mathrm{c}$ & 913 & Na2EDTA & e & 766 & Na2EDTA & $\mathrm{d}$ & 749 \\
\hline DTPA & $\mathrm{e}$ & 244 & DTPA & $\mathrm{d}$ & 159 & DTPA & $\mathrm{f}$ & 155 & DTPA & $\mathrm{e}$ & 174 \\
\hline $\mathrm{CH}_{3} \mathrm{COOH}$ & $\mathrm{f}$ & 62 & $\mathrm{CH}_{3} \mathrm{COOH}$ & d & 54 & $\mathrm{CH}_{3} \mathrm{COOH}$ & g & 53 & $\mathrm{CH}_{3} \mathrm{COOH}$ & e & 41 \\
\hline $\mathrm{NH}_{4} \mathrm{NO}_{3}$ & $\mathrm{f}$ & 13 & $\mathrm{NH}_{4} \mathrm{NO}_{3}$ & d & 7 & $\mathrm{NH}_{4} \mathrm{NO}_{3}$ & g & 8 & $\mathrm{NH}_{4} \mathrm{NO}_{3}$ & $\mathrm{e}$ & 9 \\
\hline $\mathrm{CaCl}_{2}$ & $\mathrm{f}$ & 8 & $\mathrm{CaCl}_{2}$ & d & 6 & $\mathrm{CaCl}_{2}$ & $\mathrm{~g}$ & 5 & $\mathrm{CaCl}_{2}$ & $\mathrm{e}$ & 8 \\
\hline
\end{tabular}

The results of Tukey's HSD test for metals revealed four main groups which were significantly different from each other at 0.05 in each compost (Table 4 ). The first group consisted of Fe, which had the biggest influence on the amount of nutrients in the compost. The second group contained $\mathrm{Zn}$, the third group $-\mathrm{Cu}$ and $\mathrm{Mn}$, the fourth group $-\mathrm{Ni}$, which was the least influential.

There were four to seven significantly different groups of extractants (Table 5), depending on the compost. The smallest number of groups was observed in the second compost, whereas the most groups were observed in the third compost. In each case extractant $\mathrm{HCH}$ was included in the first group as it had the biggest influence on the amount of nutrients in the composts. Extractants $\mathrm{CH}_{3} \mathrm{COOH}, \mathrm{NH}_{4} \mathrm{NO}_{3}$ and $\mathrm{CaCl}_{2}$ were included in the last group. They had much lesser influence on the amount of nutrients in the composts than the other extractants.

\section{Principal component analysis}

We made the PCA in two frames. In the first frame we analysed combined data from the four composts for each metal separately. For example, the results for $\mathrm{Cu}$ are shown in Figure 1. In the second frame we analysed data for each element and each compost separately (see Figure 2 for $\mathrm{Cu}$ as an example). Biplots for Fe, Mn, Ni and $\mathrm{Zn}$ can be found in Supplement 1.

There were 3 groups of highly correlated extractants for $\mathrm{Cu}$ (Fig. 1): $\mathrm{NH}_{4} \mathrm{NO}_{3}$, $\mathrm{CaCl}_{2}, \mathrm{HNO}_{3}, \mathrm{FAC}$ (group 1), DPTA, $\mathrm{CH}_{3} \mathrm{COOH}, \mathrm{HCl1}$ (group 2), $\mathrm{HClO}_{5}, \mathrm{EDTA}$, $\mathrm{Na}_{2}$ EDTA (group 3). It was mostly PC1 that accounted for variability across composts $\mathrm{C} 1, \mathrm{C} 2$, and $\mathrm{C} 4$. Each colour in the plot shows one of the four composts. The extractants 
Szabelska-Beręsewicz, A., Jakubus, M., Siatkowski, I. (2018). Multivariate analysis used for evaluation of the bioavailability of heavy metals in various composts. Nauka Przyr. Technol., 12, 2, 221-235. http://dx.doi.org/ 10.17306/J.NPT.00244

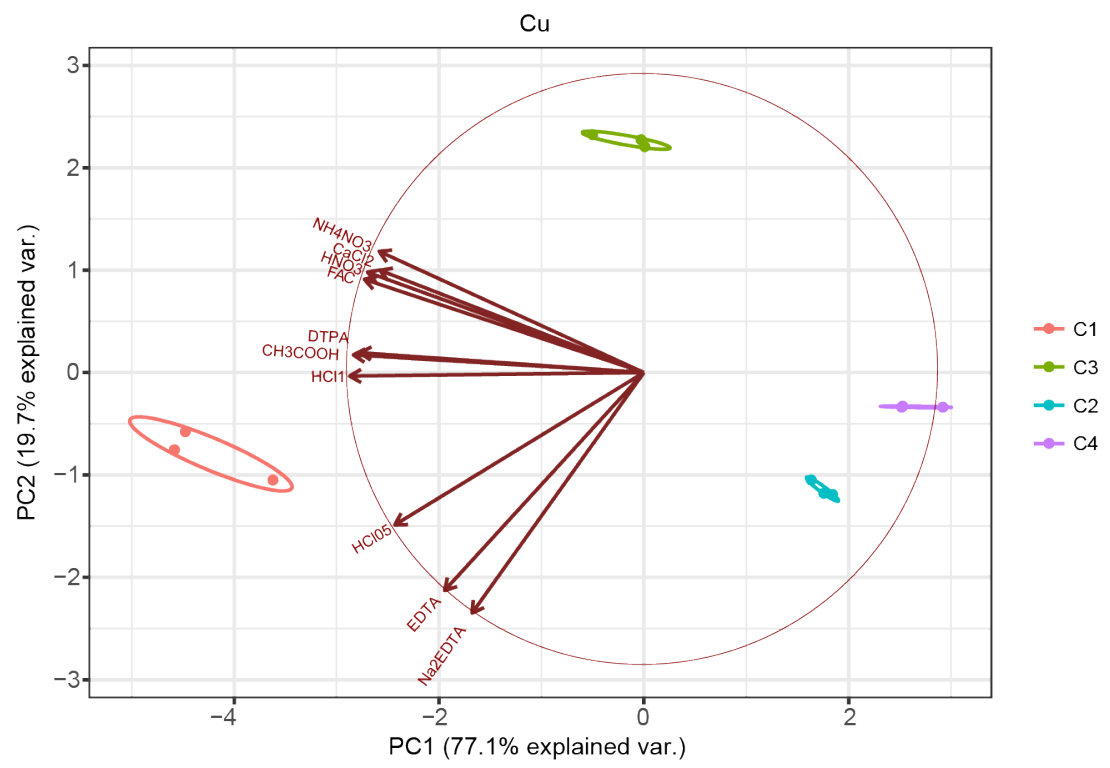

Fig. 1. A PCA biplot showing the influence of the extractants and composts on the $\mathrm{Cu}$ content

in $\mathrm{C} 1$ had the biggest influence on the content of $\mathrm{Cu}$, whereas those in $\mathrm{C} 4$ had the smallest influence.

Similarly to $\mathrm{Cu}$, the same groups of extractants could be distinguished for Fe (Fig. S1-1) and Zn (Fig. S1-7), whereas there were four groups for Mn (Fig. S1-3). The first group consisted of $\mathrm{Na} 2 \mathrm{EDTA}, \mathrm{HClO}_{5}, \mathrm{CaCl}_{2}, \mathrm{NH}_{4} \mathrm{NO}_{3}$ and DPTA. The second group included $\mathrm{HCl1}$. The third group included $\mathrm{HNO}_{3}$ and EDTA. The last group consisted of FAC and $\mathrm{CH}_{3} \mathrm{COOH}$. Apart from that, extractants $\mathrm{Na}$ 2EDTA and $\mathrm{HClO}_{5}$ had the biggest influence on the content of $\mathrm{Mn}$ in $\mathrm{C} 4$, whereas $\mathrm{FAC}$ and $\mathrm{CH}_{3} \mathrm{COOH}$ had the biggest influence on the content of $\mathrm{Mn}$ in $\mathrm{C} 2$.

There were five groups distinguished for $\mathrm{Ni}$ (S1-5). The first group consisted of $\mathrm{CH}_{3} \mathrm{COOH}$, EDTA, $\mathrm{CaCl}_{2}$ and DPTA. The second group included $\mathrm{NH}_{4} \mathrm{NO}_{3}$. The third group consisted of $\mathrm{HClO}_{5}$ and $\mathrm{Na} 2 \mathrm{EDTA}$. The fourth group consisted of $\mathrm{HCll}$ and FAC. The fifth group included $\mathrm{HNO}_{3}$. The first group had the biggest influence on the content of $\mathrm{Ni}$ in compost $\mathrm{C} 3$. Apart from that, the first and second groups had the biggest influence on the content of $\mathrm{Ni}$ in $\mathrm{C} 1$. The fourth group had the biggest influence on the content of $\mathrm{Ni}$ in $\mathrm{C} 4$. On the other hand, $\mathrm{HNO}_{3}$ (the fifth group) had minimal influence on the content of $\mathrm{Ni}$ in each compost.

Each extractant in each compost had similar influence on $\mathrm{Cu}$ (Fig. 2). However, the correlations between the extractants differed between the composts. In particular, in composts $\mathrm{C} 1, \mathrm{C} 2$ and $\mathrm{C} 3$ the Na2EDTA extractant was rather weakly correlated with the other extractants, whereas in compost $\mathrm{C} 4$ it was highly correlated with extractants $\mathrm{NH}_{4} \mathrm{NO}_{3}$ and $\mathrm{CH}_{3} \mathrm{COOH}$. The other extractants did not exhibit the same tendencies in the four composts. 
Szabelska-Beręsewicz, A., Jakubus, M., Siatkowski, I. (2018). Multivariate analysis used for evaluation of the bioavailability of heavy metals in various composts. Nauka Przyr. Technol., 12, 2, 221-235. http://dx.doi.org/ 10.17306/J.NPT.00244

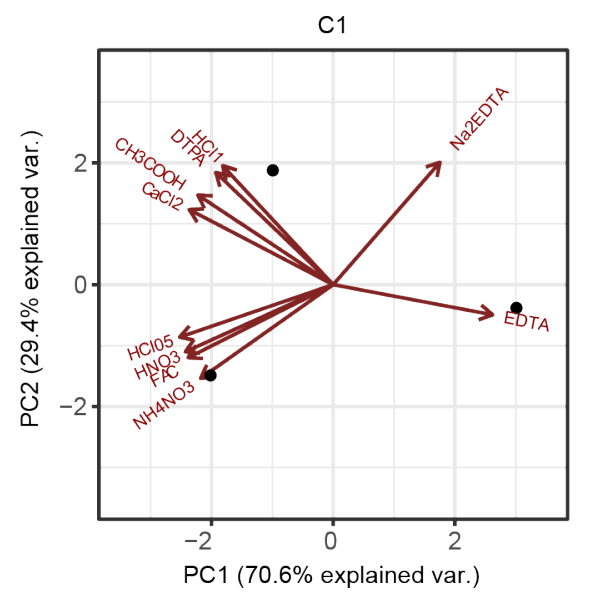

$\mathrm{Cu}$
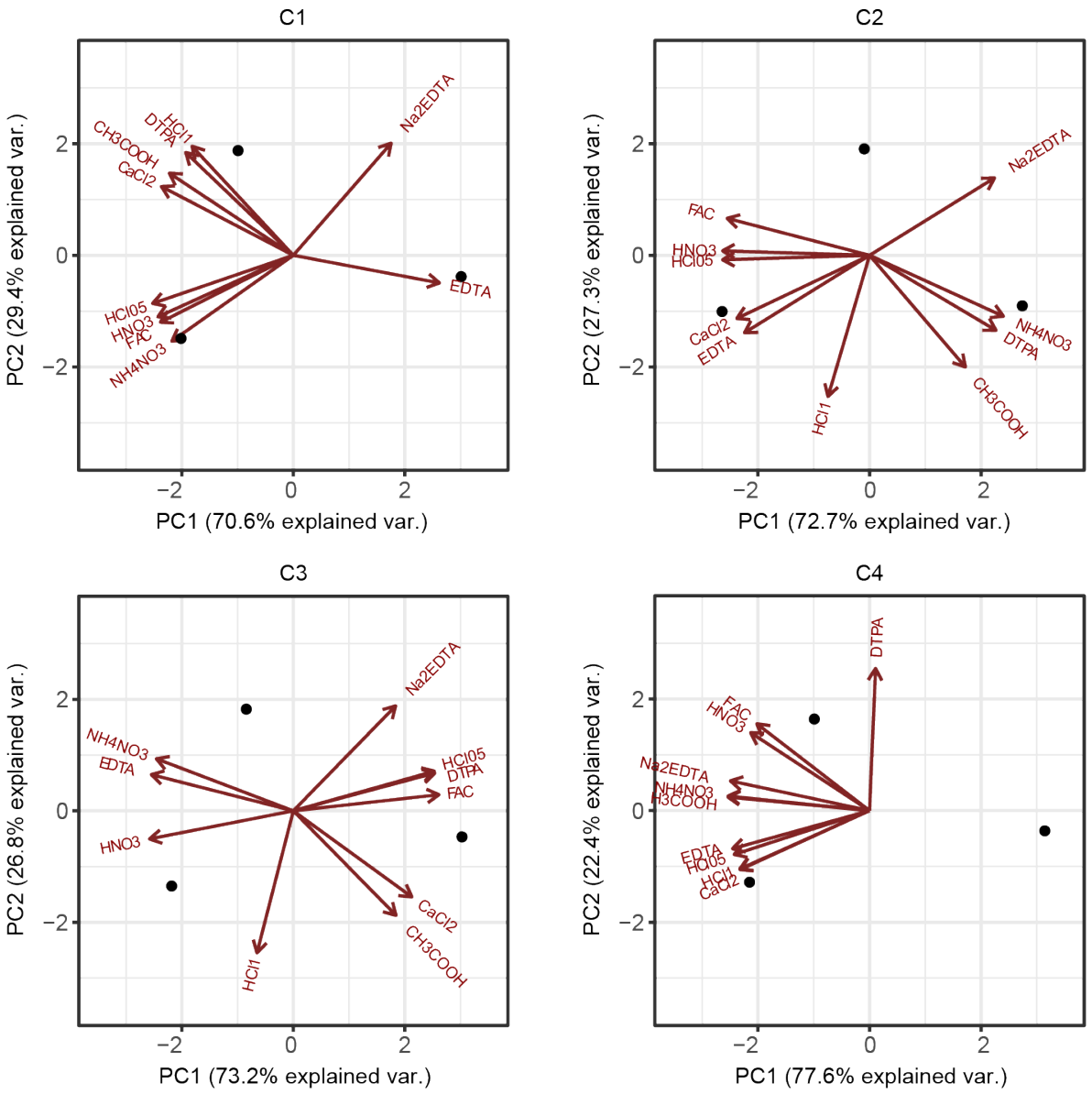

Fig. 2. A PCA biplot showing the influence of the extractants on the $\mathrm{Cu}$ content in different composts

\section{Cluster Analysis}

The result of CA is shown as a dendrogram, where the distance between two objects corresponds to the similarity or dissimilarity between the metal and extractant, i.e. the greater the distance is, the smaller the similarity is (Fig. 3 for C1).

The dendrogram revealed three main groups that were not homogeneous with respect to metals and extractants. The result suggests that both metals and extractants should be included in the analysis. The dendrograms for composts $2-4$ can be found in Supplement 2. 
Szabelska-Beressewicz, A., Jakubus, M., Siatkowski, I. (2018). Multivariate analysis used for evaluation of the bioavailability of heavy metals in various composts. Nauka Przyr. Technol., 12, 2, 221-235. http://dx.doi.org/ 10.17306/J.NPT.00244

C1

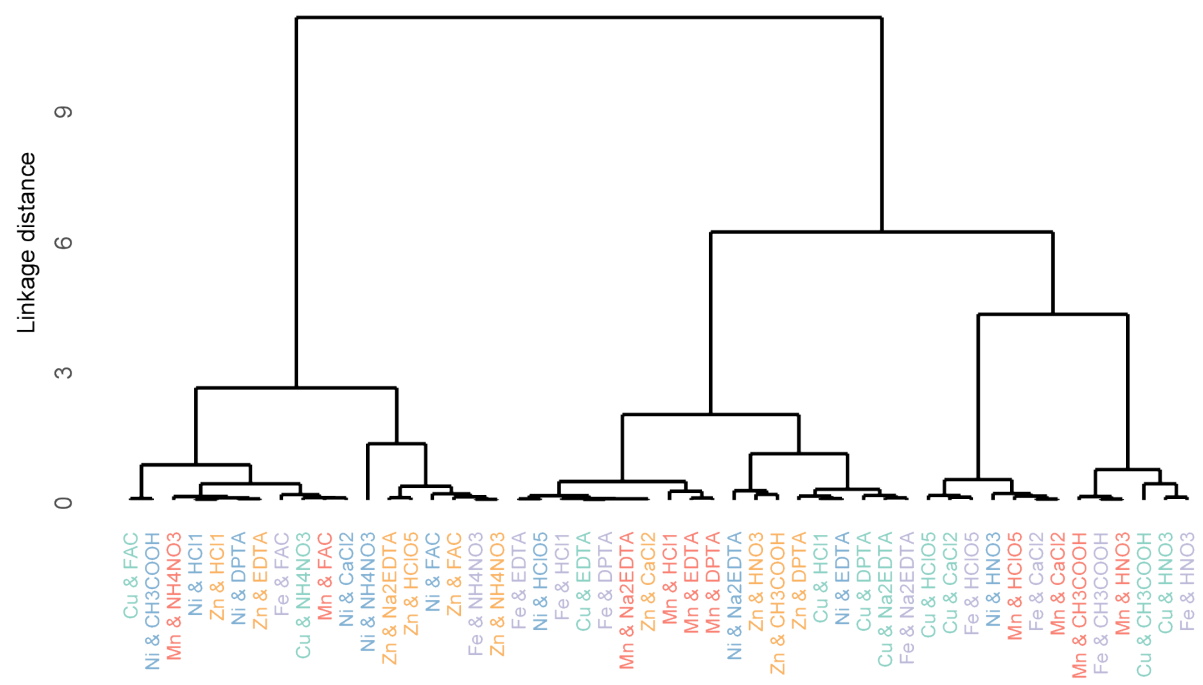

Fig. 3. A dendrogram showing the similarity and dissimilarity between objects, metals and extractanst in compost 1 . The colours refer to metals

\section{Conclusions}

1. Multivariate statistical techniques, such as MANOVA, PCA and CA, helped to interpret complex data and better understand the influence of extractants and metals in the study on sewage sludge.

2. The MANOVA showed that the metals, extractants and the interactions between the metals and extractants were statistically significant. Tukey's HSD test for multiple comparisons indicated groups of metals or extractants with similar influence on the content of nutrients in the composts and showed the hierarchy of this influence.

3. On the one hand, the PCA enabled the analysis of the influence of the extractants on the content of metals in combined analysis of all the composts. On the other hand, it resulted in biplots showing the influence of the extractants on the contamination of metals in each compost separately.

4. $\mathrm{CA}$ in the form of dendrograms showed the objects (metal and extractant) that were similar in individual composts separately.

5. Each method provided a different approach to the analysis and should be interpreted differently. It is important that they enabled multivariate analysis of composts, metals and extractants together. On the other hand, univariate analysis gave more specific results for each compost, metal and extractant considered separately.

\section{Acknowledgements}

We would like to thank two anonymous reviewers for their encouraging comments and suggestions. 
Szabelska-Beręsewicz, A., Jakubus, M., Siatkowski, I. (2018). Multivariate analysis used for evaluation of the bioavailability of heavy metals in various composts. Nauka Przyr. Technol., 12, 2, 221-235. http://dx.doi.org/ 10.17306/J.NPT.00244

\section{Supplement 1}

Biplots for Fe, Mn, Ni and Zn.

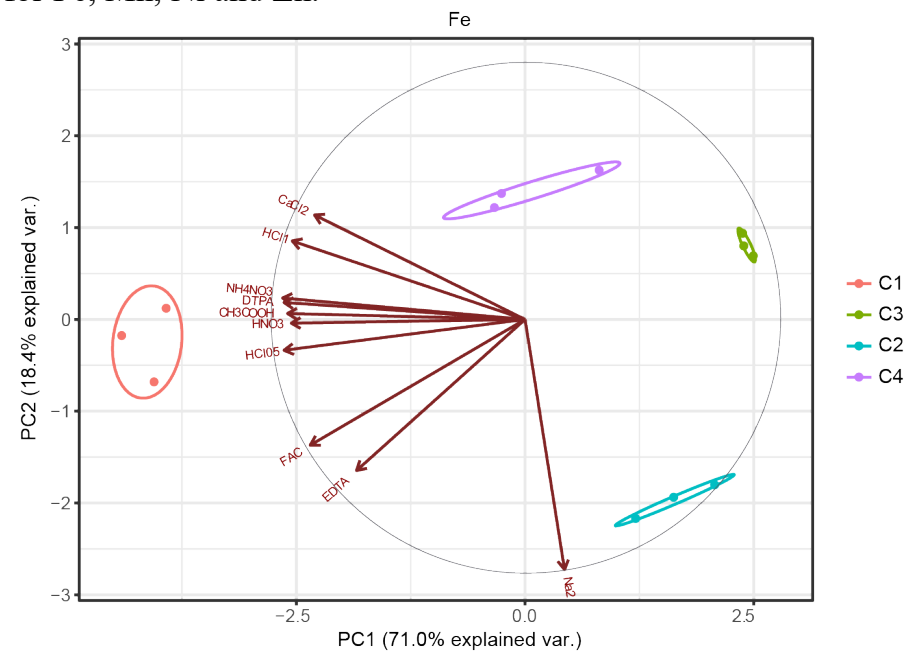

Fig. S1-1. A PCA biplot showing the influence of the extractants and composts on the Fe content

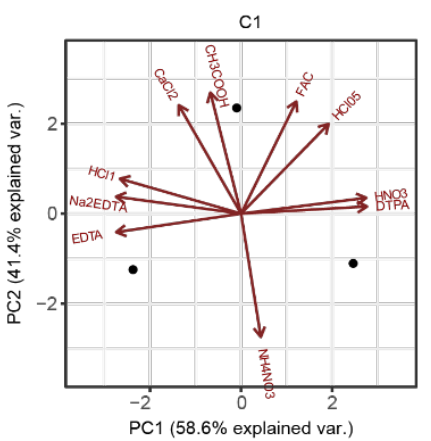

$\mathrm{Fe}$
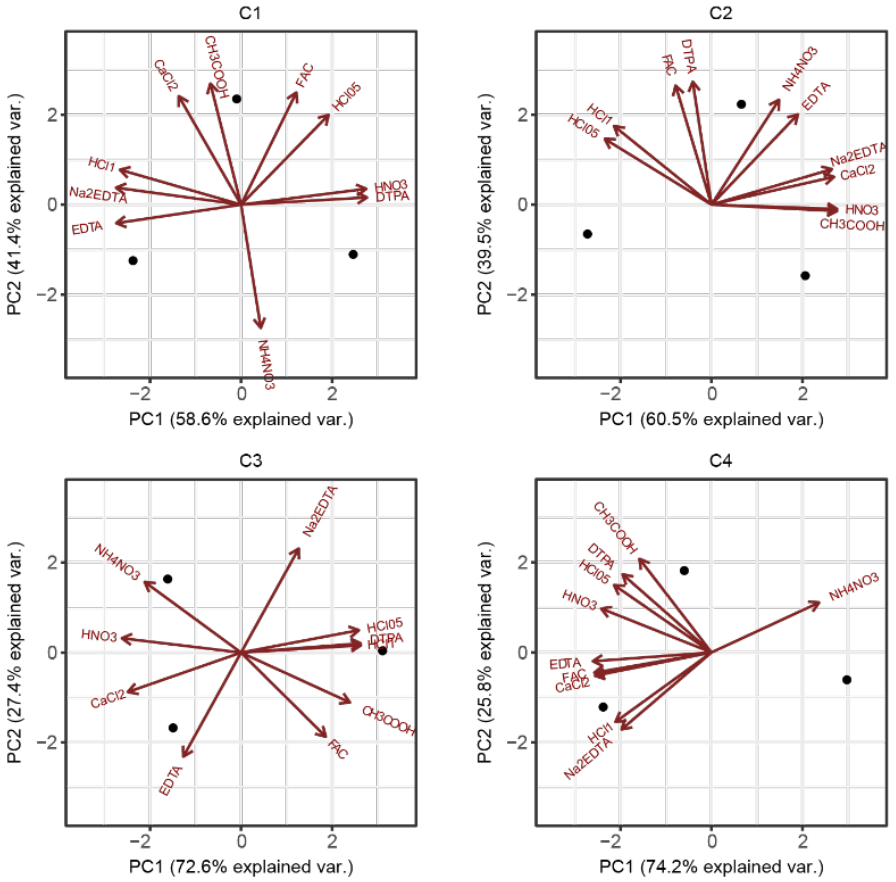

Fig. S1-2. A PCA biplot showing the influence of the extractants on the Fe content in different composts 
Szabelska-Beręsewicz, A., Jakubus, M., Siatkowski, I. (2018). Multivariate analysis used for evaluation of the bioavailability of heavy metals in various composts. Nauka Przyr. Technol., 12, 2, 221-235. http://dx.doi.org/ 10.17306/J.NPT.00244

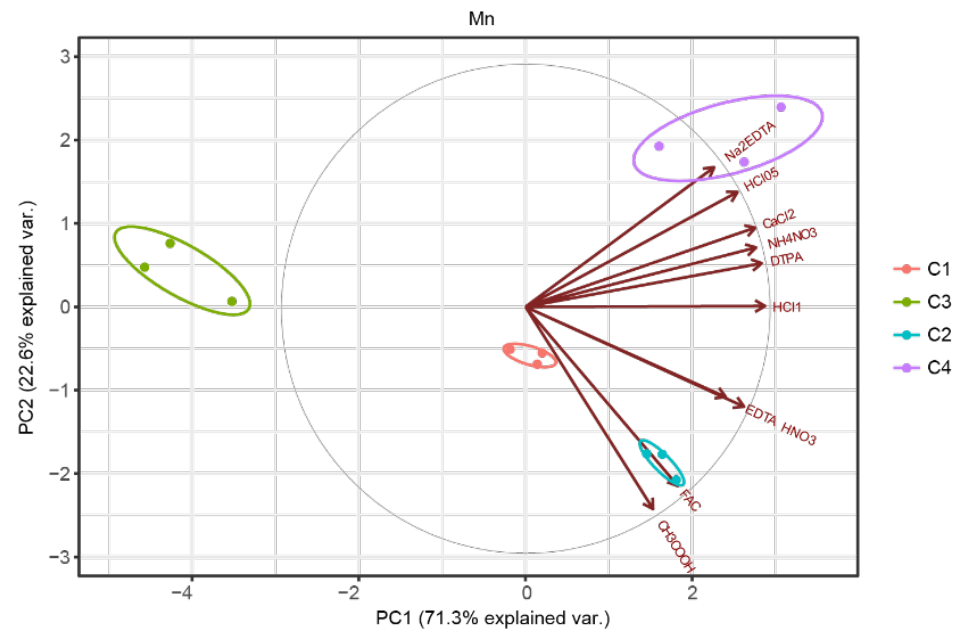

Fig. S1-3. A PCA biplot showing the influence of the extractants and composts on the Mn content
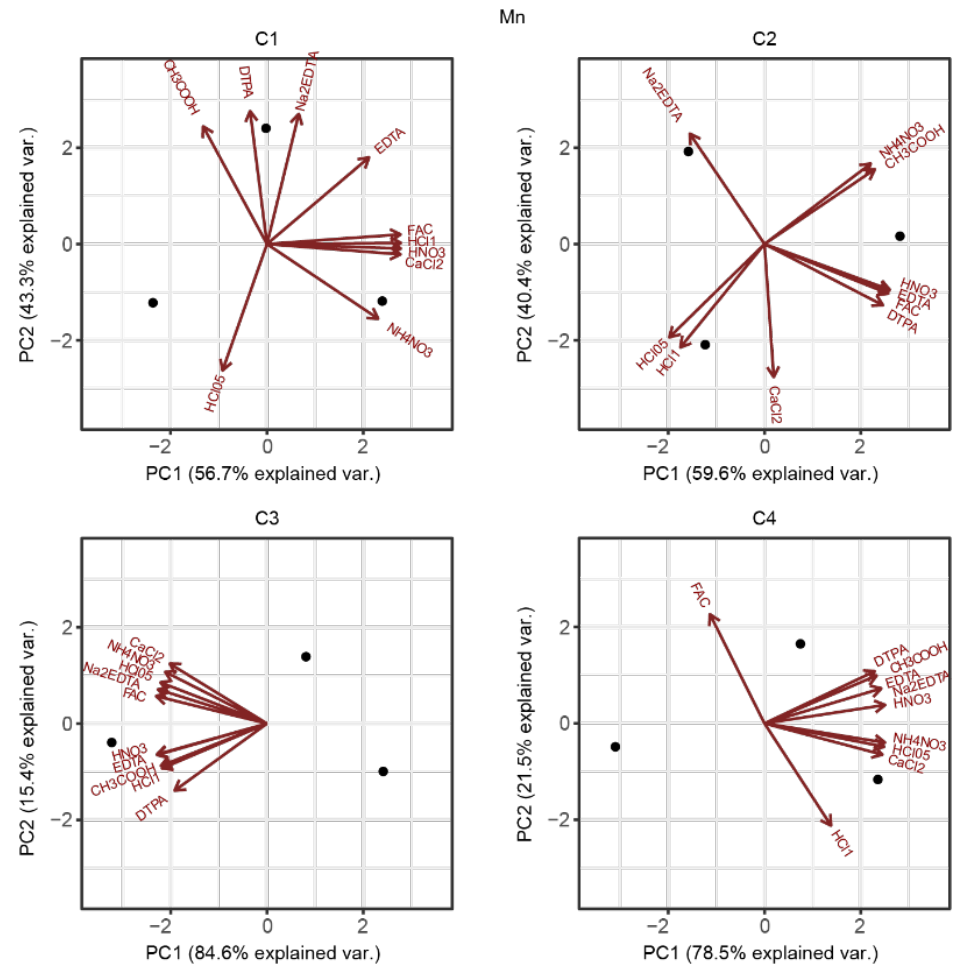

Fig. S1-4. A PCA biplot showing the influence of the extractants on the Mn content in different composts 
Szabelska-Beręsewicz, A., Jakubus, M., Siatkowski, I. (2018). Multivariate analysis used for evaluation of the bioavailability of heavy metals in various composts. Nauka Przyr. Technol., 12, 2, 221-235. http://dx.doi.org/ 10.17306/J.NPT.00244

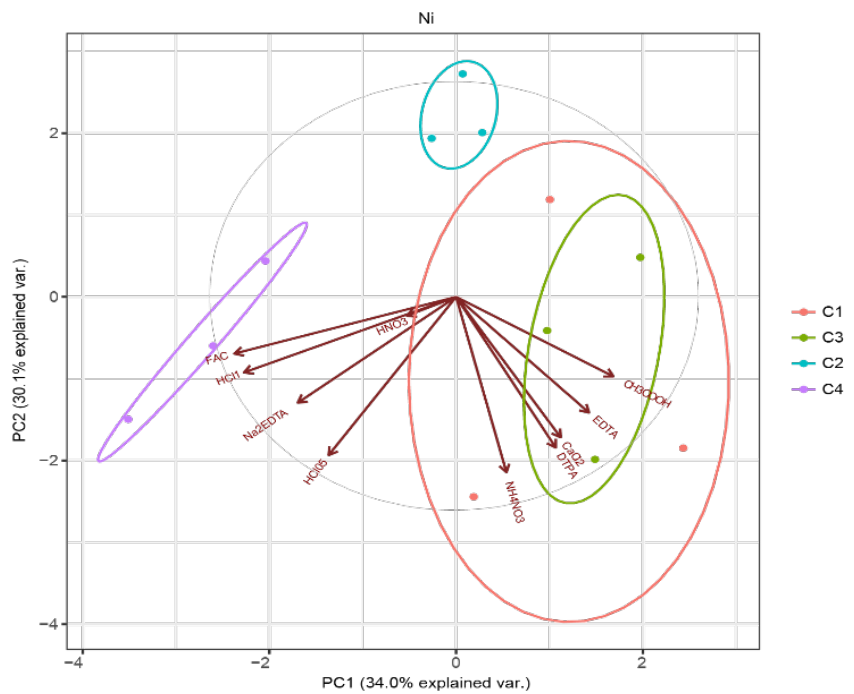

Fig. S1-5. A PCA biplot showing the influence of the extractants and composts on the $\mathrm{Ni}$ content
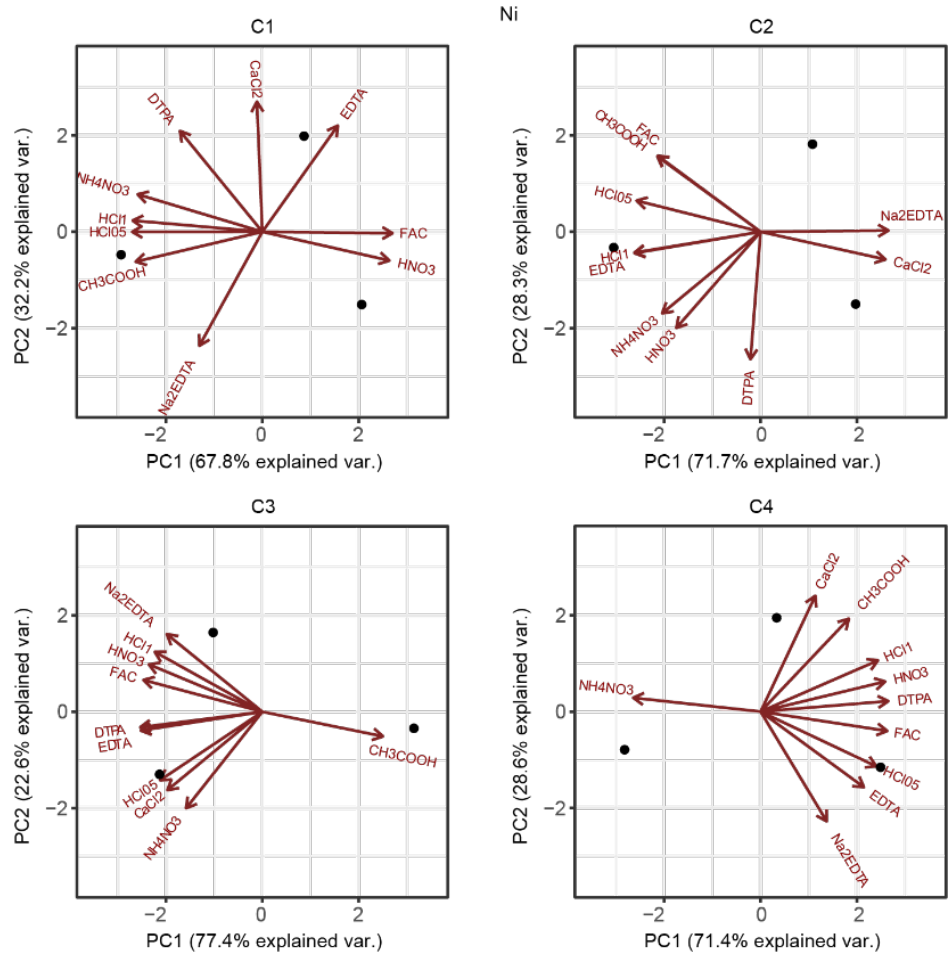

Fig. S1-6. A PCA biplot showing the influence of the extractants on the Ni content in different composts 
Szabelska-Beręsewicz, A., Jakubus, M., Siatkowski, I. (2018). Multivariate analysis used for evaluation of the bioavailability of heavy metals in various composts. Nauka Przyr. Technol., 12, 2, 221-235. http://dx.doi.org/ 10.17306/J.NPT.00244

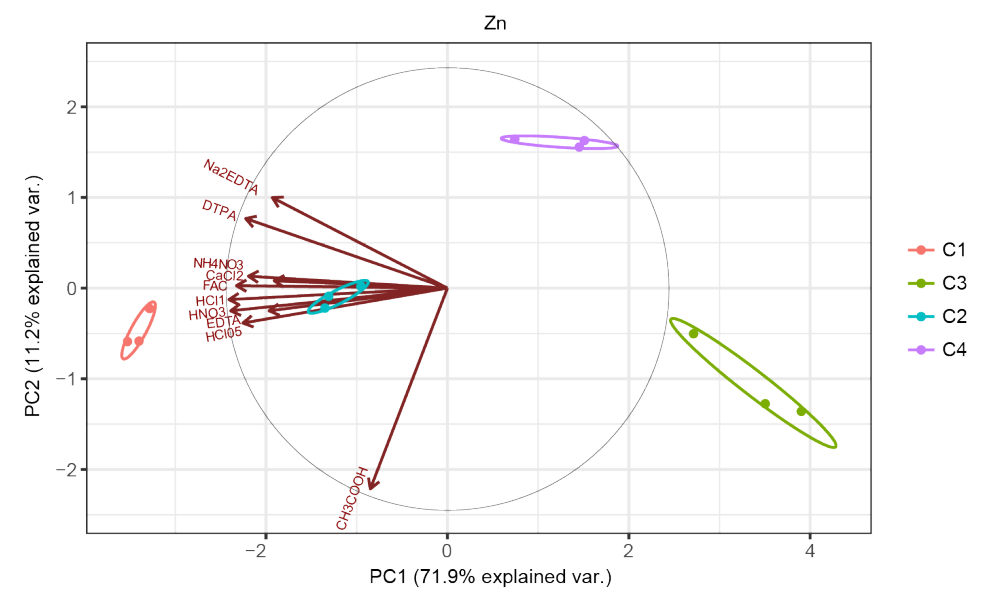

Fig. S1-7. A PCA biplot showing the influence of the extractants and composts on the Zn content

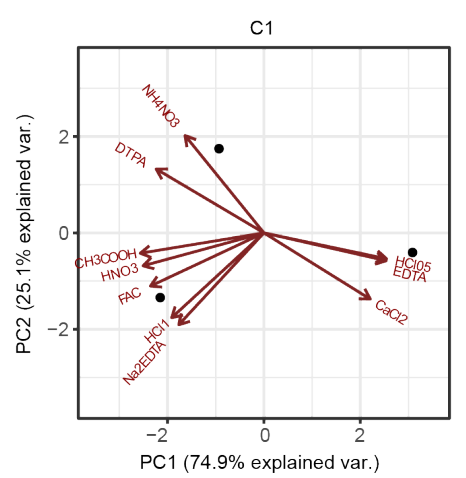

$\mathrm{Zn}$
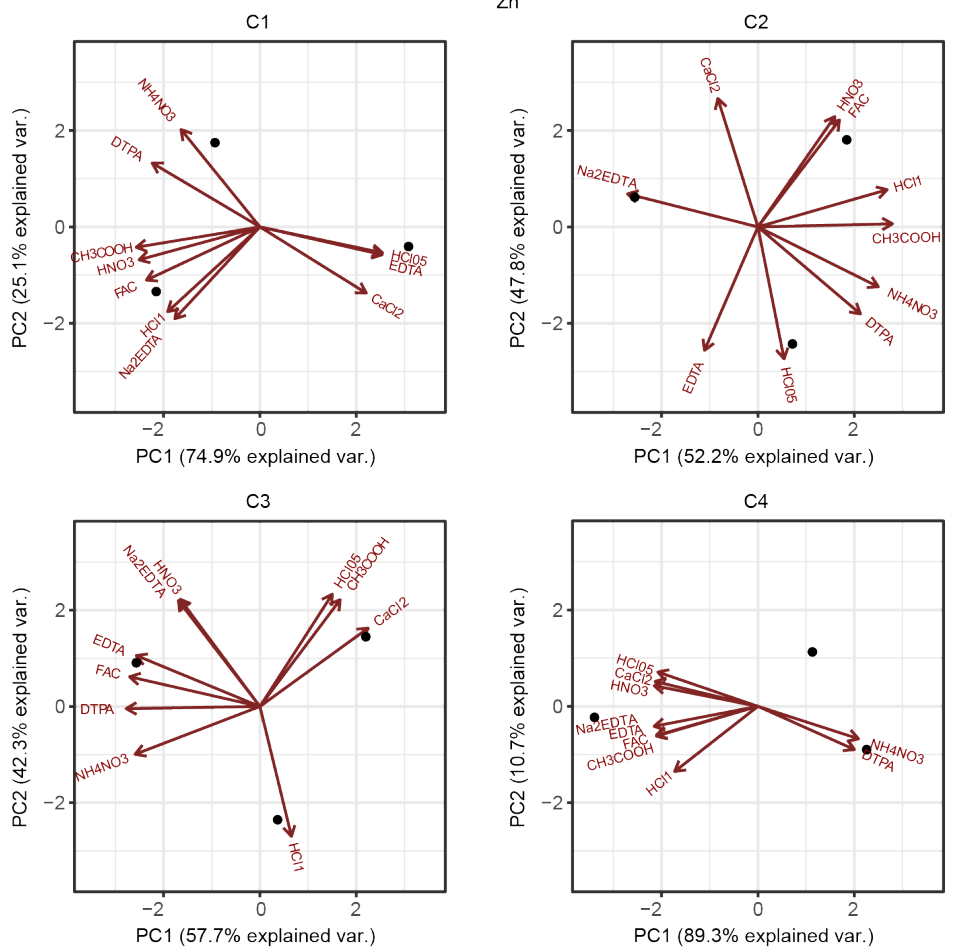

Fig. S1-8. A PCA biplot showing the influence of the extractants on the $\mathrm{Zn}$ content in different composts 
Szabelska-Beręsewicz, A., Jakubus, M., Siatkowski, I. (2018). Multivariate analysis used for evaluation of the bioavailability of heavy metals in various composts. Nauka Przyr. Technol., 12, 2, 221-235. http://dx.doi.org/ 10.17306/J.NPT.00244

\section{Supplement 2}

Dendrograms for composts $2-4$

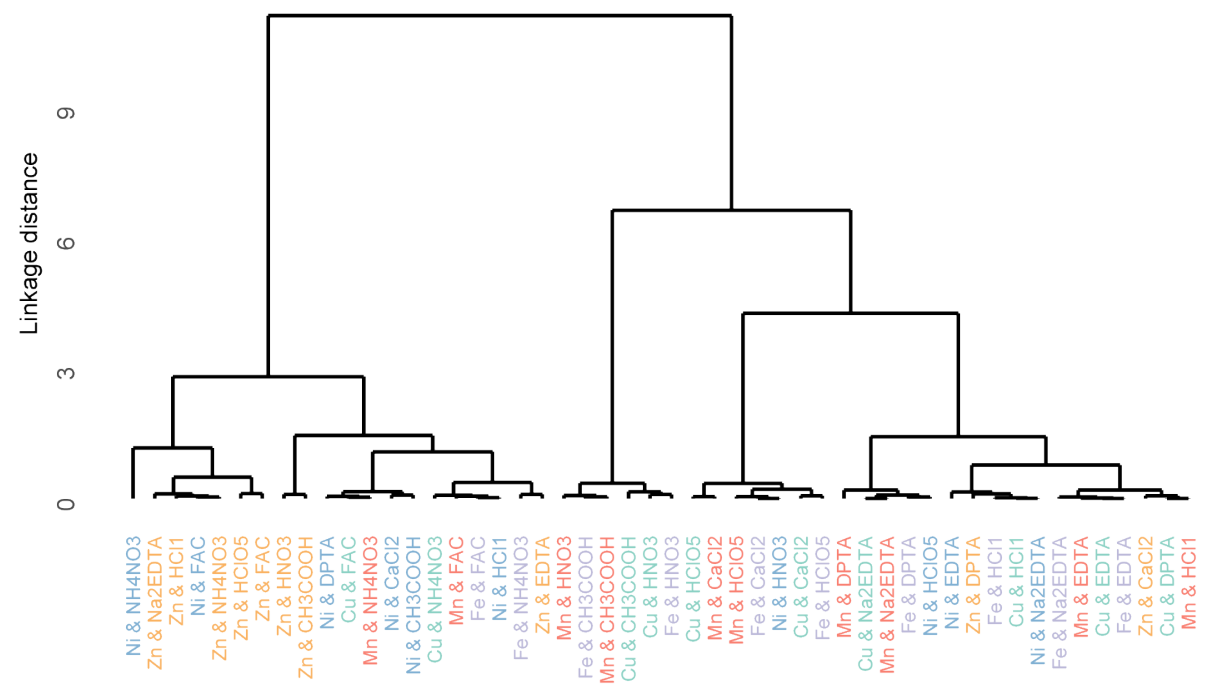

Fig. S2-1. A dendrogram showing the dissimilarity between metal and extractant objects in compost 2 . The colours refer to metals

C3

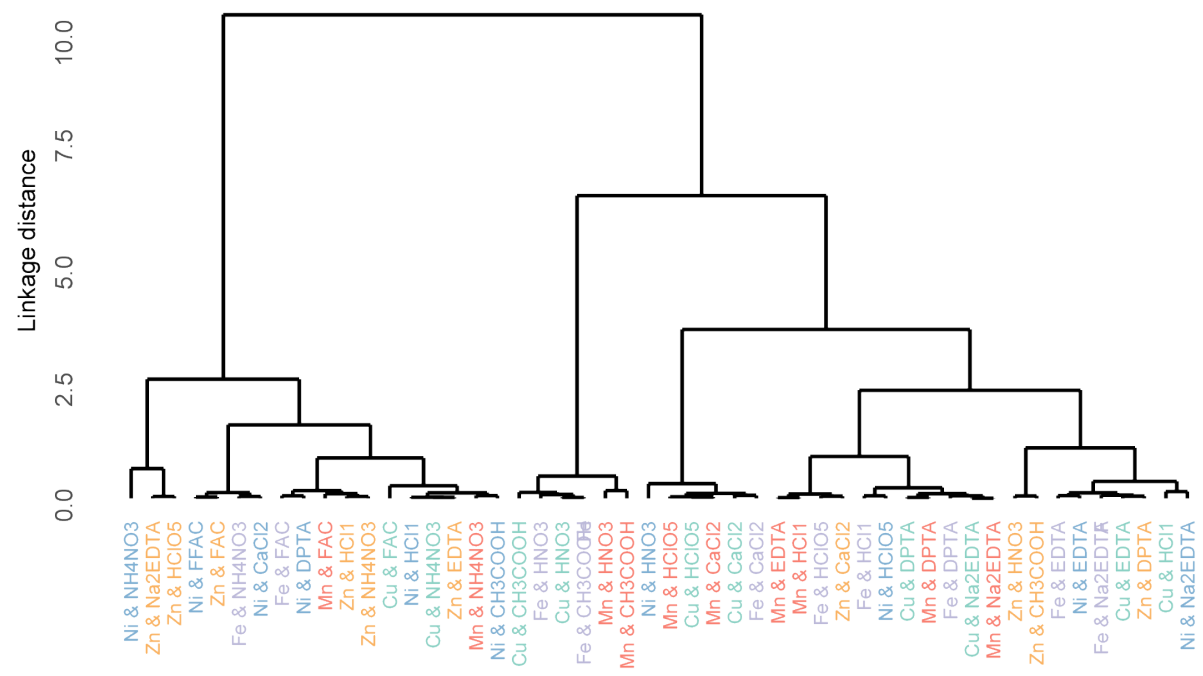

Fig. S2-2. Dendrogram representing the dissimilarity between metal and extractant objects in compost 3 . The colours refer to metals 
Szabelska-Beręsewicz, A., Jakubus, M., Siatkowski, I. (2018). Multivariate analysis used for evaluation of the bioavailability of heavy metals in various composts. Nauka Przyr. Technol., 12, 2, 221-235. http://dx.doi.org/ 10.17306/J.NPT.00244

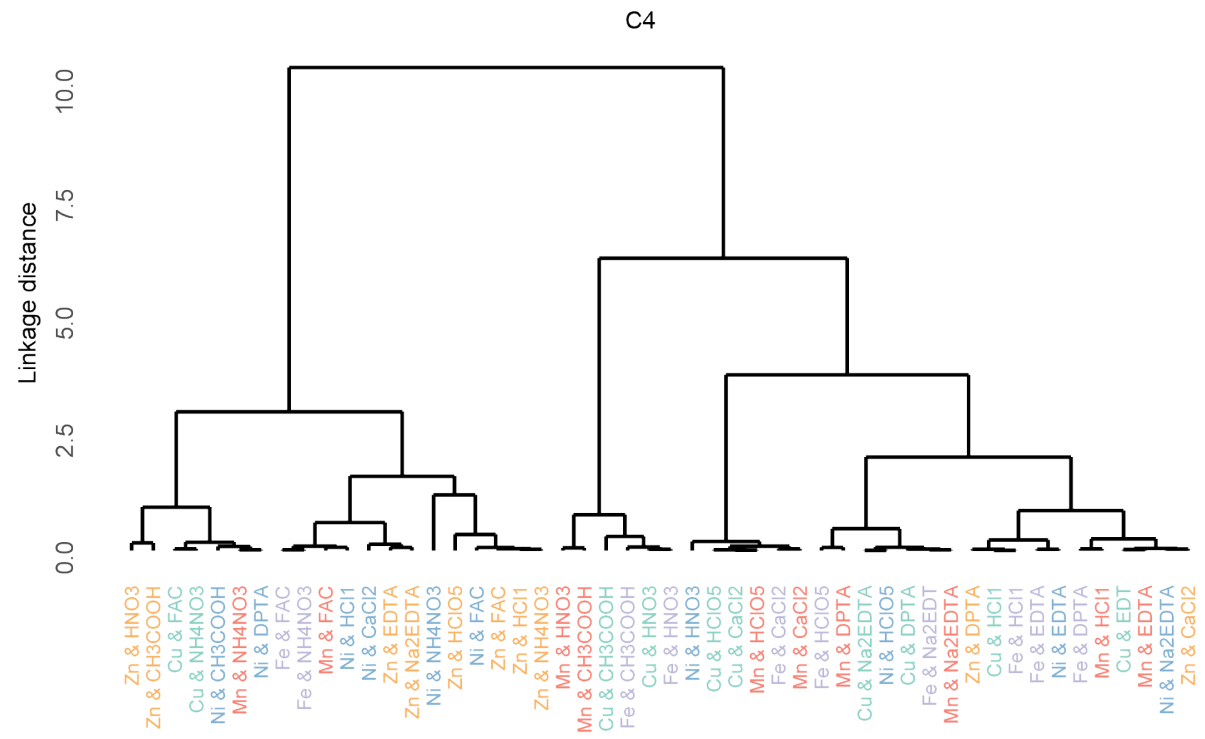

Fig. S2-3. Dendrogram representing the dissimilarity between metal and extractant objects in compost 4 . The colours refer to metals

\section{References}

Central Statistical Office. (2015). Warsaw. http://stat.gov.pl/en/basic-data/

Greenacre, M., Primicerio, R. (2013). Multivariate analysis of ecological data. Bilbao: Fundacion BBVA.

Jakubus, M. (2010). Changes of speciation and bioavailability of micronutrients during sewage sludge composting with different biowastes. Scientific Researches 405. Poznań: Wyd. UP.

Jakubus, M. (2013). Evaluation of maturity and stability parameters of composts prepared with sewage sludge. Fresen. Environ. Bull., 22, 11a, 3398-3414.

Kim, R. Y., Yoon, J. K., Kim, T. S., Yang, J. E., Owens, G., Kim, K. R. (2015). Bioavailability of heavy metals in soils: definitions and practical implementation - a critical review. Environ. Geochem. Health 37, 1041-1061. https://dx.doi.org/10.1007/s10653-015-9695-y

Mardia, K. V., Kent, J. T., Bibby, J. M. (1979). Multivariate analysis. Probability and Mathematical Statistics. London-New York: Academic Press.

R Core Team (2015). R: A language and environment for statistical computing. Viena: R Foundation for Statistical Computing. http://www.R-project.org.

Rosen, V., Chen, Y. (2014). The influence of compost addition on heavy metal distribution between operationally defined geochemical fractions and on metal accumulation in plant. J. Soils Sediments 14, 713-720. https://dx.doi.org/10.1007/s11368-013-0819-7

Quevauviller, Ph., Lachica, M., Barahona, E., Gomez, A., Rauret, G., Ure, A., Muntau, H. (1998). Certified reference material for the quality control of EDTA- and DTPA- extractable trace metals contents in calcareous soil (CMR 600). Fresen. J. Anality. Chem., 360, 505-511. https://dx.doi.org/ 10.1007/s002160050750

Šmilauer, P., Lepš, J. (2014). Multivariate analysis of ecological data using CANOCO 5. United Kingdom: Cambridge University Press. https://dx.doi.org/10.1017/CBO9781139627061 
Szabelska-Beręsewicz, A., Jakubus, M., Siatkowski, I. (2018). Multivariate analysis used for evaluation of the bioavailability of heavy metals in various composts. Nauka Przyr. Technol., 12, 2, 221-235. http://dx.doi.org/ 10.17306/J.NPT.00244

Zorpas, A. A., Loizidou, M. (2008). Sawdust and natural zeolite as a bulking agent for improving quality of a composting product from anaerobically stabilized sewage sludge. Bioresour. Technol., 99, 7545-7552. https://dx.doi.org/10.1016/j.biortech.2008.02.014

\title{
OCENA BIOPRZYSWAJALNOŚCI METALI CIĘŻKICH W RÓŻNYCH KOMPOSTACH PRZY UŻYCIU ANALIZY WIELOWYMIAROWEJ
}

\begin{abstract}
Abstrakt
Wstęp. Osady ściekowe stanowią uciążliwy środowiskowo problem, ponieważ ich obecność może przyczyniać się do wtórnego zanieczyszczenia, zatem ich właściwe zagospodarowanie stanowi bardzo ważne zagadnienie. Jedną z racjonalnych metod spożytkowania osadów ściekowych jest ich kompostowanie. Komposty stanowią cenne źródło składników pokarmowych, ale mogą wnosić do środowiska metale ciężkie. Istnieje wiele metod analizy metali ciężkich, lecz nie ma jednego, wspólnego dla nich rozwiązania, które w realny sposób odzwierciedlałoby ich bioprzyswajalność z różnych kompostów.

Material i metody. W eksperymencie użyto czterech różnych kompostów powstałych przez kompostowanie osadów ściekowych z dodatkiem substancji wypełniających. Podczas analizy danych użyto kilku wielowymiarowych technik statystycznych, takich jak: MANOVA wraz z testem Tukeya do wielokrotnych porównań, analiza składowych głównych i analiza skupień.

Wyniki. Celem badania było zweryfikowanie przydatności zastosowania metod analizy wielowymiarowej do oceny różnych ekstraktorów pozwalających właściwie określić bioprzyswajalność metali ciężkich z różnych kompostów.

Wnioski. Zastosowanie metod wielowymiarowych pozwala w interpretacji złożonych danych, w których może zostać przeprowadzona analiza łączona dla kompostów, metali oraz ekstraktorów. Pozwala to również w lepszym zrozumieniu wpływu ekstraktorów oraz roli metali w badaniu osadów ściekowych.
\end{abstract}

Słowa kluczowe: Bioprzyswajalność, komposty, metale ciężkie, ekstraktory, wielowymiarowa analiza statystyczna

Corresponding address - Adres do korespondencji:

Idzi Siatkowski, Katedra Metod Matematycznych i Statystycznych, Uniwersytet Przyrodniczy w Poznaniu, ul.Wojska Polskiego 28, 60-637 Poznań, e-mail: idzi.siatkowski@up.poznan.pl

Accepted for publication - Zaakceptowano do opublikowania:

27.06.2018

For citation - Do cytowania:

Szabelska-Beręsewicz, A., Jakubus, M., Siatkowski, I. (2018). Multivariate analysis used for evaluation of the bioavailability of heavy metals in various composts. Nauka Przyr. Technol., 12, 2, 221-235. http://dx.doi.org/10.17306/J.NPT.00244 